\title{
Influence of gamma irradiation and low temperature storage on the quality and shelf life of squid (Doryteuthis sibogae)
}

\author{
${ }^{1}$ *Manjanaik, B., ${ }^{1}$ Kavya, N..${ }^{2}$ Shetty, V., ${ }^{3}$ Somashekarappa, H. and ${ }^{3}$ Rajashekar, P. \\ ${ }^{1}$ Department of Fish Processing Technology, Karnataka Veterinary, Animal and Fisheries \\ Sciences University, College of Fisheries, Mangalore - 575002, India \\ ${ }^{2}$ Department of Microbiology, K. S. Hegde Medical Academy, Mangalore- 575018, India \\ ${ }^{3}$ Centre for Application of Radioisotopes and Radiation Technology (CARRT), \\ Mangalore University, Mangalore-574199, India
}

\begin{abstract}
Article history:
Received: 10 August 2017

Received in revised form: 17

August 2017

Accepted: 18 August 2017

Available Online: 23 August 2017
\end{abstract}

\section{Keywords:}

Gamma irradiation,

Squid,

Refrigeration,

TVB-N,

TBARS

\section{DOI:}

https://doi.org/10.26656/fr.2017.2(1).170

\begin{abstract}
Irradiation is considered as an efficient method for the reduction of microorganisms in food. It has been used to improve the safety and shelf life of food products. The present investigation is aimed at studying the influence of gamma irradiation ( 3 and $5 \mathrm{kGy}$ ) and subsequent storage at refrigeration temperature $\left(4^{\circ} \mathrm{C}\right)$ on the chemical, microbial qualities and extended shelf life of squid (Doryteuthis sibogae). The total volatile base nitrogen (TVB-N) and trimethyl amine nitrogen values (TMA-N) of the irradiated squid samples significantly decreased in comparison with the control (non-irradiated) stored at $4^{\circ} \mathrm{C}$. The thiobarbituric acid values for the irradiated squid was significantly lower than of the nonirradiated samples stored at $4^{\circ} \mathrm{C}(\mathrm{p}<0.05)$. The $\mathrm{pH}$ value of the squid was affected significantly by both, irradiation dose and storage temperature $(\mathrm{p}<0.05)$. The total microbial load for the non-irradiated squid samples was higher than those of irradiated samples at $4^{\circ} \mathrm{C}$ temperature. The results revealed that the combination of irradiation and refrigerated storage resulted in a significant reduction of microbial growth and stabilized the biochemical characteristics of squid.
\end{abstract}

\section{Introduction}

Cephalopods are a highly developed group of invertebrates and occupy a leading place among the exploited marine fishery resources of the world because of their abundance and high nutritional quality. They constitute $4-5 \%$ of the total marine fish production from the Indian waters (Neethiselvan et al., 2001). Although there are more than 1000 species of cephalopods, only a few species such as the squid, cuttlefish, and the octopus are commercially exploited. Cephalopods are marketed in various forms such as fresh, frozen, canned, dried, salted or smoked. Over the past few decades, irradiation has been used as an effective method for improving the sanitary, phytosanitary, and shelf life of a wide range of food products (Smith and Pillai, 2004). The significance of irradiation as phytosanitary treatment of horticultural products for international trade has been described by Bustos-Griffin et al. (2015). The World Health Organisation (WHO), the Food and Agriculture Organisation (FAO), the International Atomic Energy
Agency (IAEA), and the Codex Alimentarius Commission (CAC) have been advocating and facilitating the use of irradiation as a food safety method throughout the world. So far, more than 50 countries have approved irradiation as a sanitary and phytosanitary method for over 60 food and food products (ICGFI, 2002). Food exposed to irradiation undergoes chemical changes without compromising its nutritional quality (Venugopal et al., 1999; ICGFI, 2002). Gamma irradiation has been used as an effective method to extend the shelf life of fish products by reducing its microbial population qualitatively and quantitatively (Arvanitoyannis and Stratakos, 2010) and extending the quality of the seafood. Squids, the most commercially important cephalopod, are highly perishable and prone to microbial spoilage. As there are limited studies on the effect of gamma irradiation on the quality and shelf life of squid (Doryteuthis sibogae), the present work aims to study the biochemical and microbial changes in this squid species upon irradiation and subsequent storage at refrigerated temperature. 


\section{Materials and methods}

\subsection{Materials}

Fresh squid (Doryteuthis sibogae) was procured from the Fish Landing Centre located at Mangaluru, India. The sample was immediately packed in polyethylene bags with ice and brought to the laboratory and stored at $4{ }^{\circ} \mathrm{C}$ until irradiation.

\subsection{Irradiation}

The samples were divided into two groups and subjected to irradiation at the Centre for Application of Radioisotope and Radiation Technology (CARRT), Mangalore University, India using ${ }^{60}$ cobalt radiation source (BRIT, Mumbai). The two sample groups were irradiated with $3.0 \mathrm{kGy}$ and $5.0 \mathrm{kGy}$ at a dose rate of $6.94 \mathrm{kGy} / \mathrm{h}$. The radiation dose was monitored using the Freaky dosimeter. The samples were maintained at $4 \pm 1^{\circ} \mathrm{C}$ using sealed ice covering during irradiation. After irradiation, the samples were iced and transported within $1 \mathrm{~h}$ to the laboratory and held at refrigeration $\left(4^{\circ} \mathrm{C}\right)$ temperature until the last day of the experiment. The experiment was carried out in triplicate.

\subsection{Bio- chemical analysis}

A proximate composition of the fresh squid meat was carried out. The moisture content was determined by the hot air oven method. The crude protein content of the squid meat was analysed for total nitrogen content by the Kjeldahl method. The crude lipid content of the squid meat was determined by the Soxhlet extraction method (AOAC, 2010). The ash content of the meat was determined by the method described in AOAC (2010). The total volatile base nitrogen (TVB-N) and Trimethyl amine nitrogen (TMA-N) content were determined by the Conway micro-diffusion method (Beatty and Gibbon, 1937) and expressed as mg N/100 g meat. The thiobarbituric acid reactive substances (TBARS) (Raghavan and Hultin, 2005) was expressed as $\mathrm{mg}$ malonaldehyde $/ \mathrm{kg}$ meat. The $\mathrm{pH}$ was measured at room temperature on the homogenates of the samples in distilled water $(1 / 10 \mathrm{w} / \mathrm{w})$ (Vyncke, 1981) and monitored using the $\mathrm{pH}$ meter (Systronix 361, India).

\subsection{Microbial analysis}

The aerobic mesophilic counts and bacterial pathogens were analysed throughout the experiment. Twenty- five grams of the sample was placed aseptically into a sterile blender containing $225 \mathrm{ml}$ of sterilized physiological saline $(0.85 \% \mathrm{NaCl})$ and blended for $3 \mathrm{~min}$ at low speed. About $0.1 \mathrm{ml}$ of serially diluted homogenates were plated onto a plate count agar
(Himedia, Mumbai, India) incubated at $35^{\circ} \mathrm{C}$ for $24-48 \mathrm{~h}$ and the total plate counts were reported as CFU/g. The coliforms were enumerated by the MPN method. Pathogens such as the Escherichia coli (EMB agar, Himedia, Mumbai), Staphylococcus aureus (Baird parker agar, Himedia, Mumbai), Salmonella (BSA agar, Himedia, Mumbai), and Vibrios (TCBS, Himedia, Mumbai) were analysed (APHA, 2000 and ICMSF, 1986). The microbial counts were expressed as the number of viable bacterial colonies per gram of meat $(\log \mathrm{CFU} / \mathrm{g})$.

\subsection{Statistical analysis}

The data obtained from the microbiological and biochemical analyses were subjected to statistical analysis using the Standard Statistical Package (SPSS, version 21.00). Analysis of Variance (one way ANOVA) was performed to examine whether any significant difference existed for the values obtained with respect to the number of storage days. The significance of differences was calculated at $5 \%$ level ( $p$ $<0.05)$

\section{Results and discussion}

Among the sea foods consumed, squid and shrimp are rich in proteins, free amino acids, minerals, and other soluble nitrogenous substances (Hocaoglu et al., 2012). In the present study, the proximate composition estimated for fresh squid was $79.04 \%$ moisture; $18.69 \%$ protein; $2.32 \%$ crude lipids, and $1.05 \%$ ash content which was comparable to the values reported in earlier studies by Hocaoglu et al. (2012) and Viji et al. (2014).

\subsection{Biochemical analysis of squid at refrigeration temperature $\left(4^{\circ} \mathrm{C}\right)$}

\subsubsection{Total volatile base nitrogen (TVB-N)}

During the period of refrigerated storage $\left(4^{\circ} \mathrm{C}\right)$, the TVB-N value of the squid meat was significantly $(p<0.05)$ higher in the non-irradiated (control) samples than in the irradiated samples (Table 1 and Figure 2). The initial TVB-N value in the control sample was 5.37 $\mathrm{mg} \mathrm{N} / 100 \mathrm{~g}$, which increased to $56.93 \mathrm{mg} \mathrm{N} / 100 \mathrm{~g}$ at the end of 10 days of the storage period. On the other hand, irradiation at 3 and $5 \mathrm{kGy}$ suppressed the formation of TVB-N during storage and the value reached 30.33 and $24.27 \mathrm{mg} \mathrm{N} / 100 \mathrm{~g}$, respectively, after 10 days. The irradiated samples of the squid had significantly much lower concentrations of TVB-N during its refrigerated storage as compared to the control, which may be attributed to the reduction of the microbial population 
Table 1. Biochemical analysis of control and irradiated squid during refrigerated storage $\left(4^{\circ} \mathrm{C}\right)$

\begin{tabular}{ccccccc}
\hline \multirow{2}{*}{ Parameters } & Dose & \multicolumn{5}{c}{ No. of Storage Days } \\
\cline { 3 - 7 } & & 1 & 3 & 5 & 7 & 10 \\
\hline TVB-N & Control & $5.37 \pm 0.81^{\mathrm{aA}}$ & $13.53 \pm 1.62^{\mathrm{bB}}$ & $21.93 \pm 0.81^{\mathrm{cC}}$ & $42.00 \pm 1.4^{\mathrm{dC}}$ & $56.93 \pm 0.81^{\mathrm{eC}}$ \\
$(\mathrm{mg} \mathrm{N} / 100 \mathrm{~g})$ & $3 \mathrm{kGy}$ & $8.17 \pm 1.62^{\mathrm{aB}}$ & $12.60 \pm 1.4^{\mathrm{bB}}$ & $14.93 \pm 0.81^{\mathrm{bB}}$ & $13.07 \pm 1.62^{\mathrm{bB}}$ & $30.33 \pm 0.81^{\mathrm{cB}}$ \\
& $5 \mathrm{kGy}$ & $5.83 \pm 0.81^{\mathrm{aA}}$ & $8.63 \pm 2.02^{\mathrm{bA}}$ & $8.63 \pm 2.02^{\mathrm{bA}}$ & $7.00 \pm 0.0^{\mathrm{abA}}$ & $24.27 \pm 0.81^{\mathrm{cA}}$ \\
TMA-N $(\mathrm{mg}$ & Control & $1.87 \pm 0.81^{\mathrm{aA}}$ & $5.13 \pm 0.81^{\mathrm{b}}$ & $6.53 \pm 0.81^{\mathrm{cB}}$ & $9.33 \pm 0.81^{\mathrm{dB}}$ & $12.60 \pm 0.00^{\mathrm{eB}}$ \\
N/100g) & $3 \mathrm{kGy}$ & $2.33 \pm 1.62^{\mathrm{aA}}$ & $3.27 \pm 0.81^{\mathrm{aA}}$ & $2.80 \pm 1.4^{\mathrm{aA}}$ & $3.27 \pm 0.81^{\mathrm{aA}}$ & $8.6 \pm 2.02^{\mathrm{bA}}$ \\
& $5 \mathrm{kGy}$ & $2.33 \pm 0.81^{\mathrm{aA}}$ & $2.33 \pm 0.81^{\mathrm{aA}}$ & $1.87 \pm 0.81^{\mathrm{aA}}$ & $2.23 \pm 0.74^{\mathrm{aA}}$ & $6.53 \pm 0.81^{\mathrm{bA}}$ \\
TBARS $(\mathrm{mg}$ & Control & $5.70 \pm 0.19^{\mathrm{bC}}$ & $3.31 \pm 0.51^{\mathrm{aA}}$ & $6.00 \pm 0.16^{\mathrm{bB}}$ & $6.96 \pm 0.24^{\mathrm{cB}}$ & $9.04 \pm 0.08^{\mathrm{dB}}$ \\
MDA $/ \mathrm{kg}$ & $3 \mathrm{kGy}$ & $5.34 \pm 0.06^{\mathrm{bB}}$ & $3.92 \pm 0.14^{\mathrm{bA}}$ & $3.26 \pm 0.07^{\mathrm{aA}}$ & $3.28 \pm 0.05^{\mathrm{aA}}$ & $1.10 \pm 0.15^{\mathrm{cA}}$ \\
& $5 \mathrm{kGy}$ & $4.35 \pm 0.09^{\mathrm{bA}}$ & $3.42 \pm 0.18^{\mathrm{aA}}$ & $5.79 \pm 0.1^{\mathrm{dB}}$ & $8.55 \pm 0.1^{\mathrm{eC}}$ & $4.72 \pm 0.26^{\mathrm{cC}}$ \\
& Control & $6.42 \pm 0.04^{\mathrm{cB}}$ & $6.29 \pm 0.02^{\mathrm{aB}}$ & $6.26 \pm 0.03^{\mathrm{aB}}$ & $6.45 \pm 0.03^{\mathrm{bC}}$ & $7.13 \pm 0.11^{\mathrm{dC}}$ \\
\cline { 3 - 7 } & $3 \mathrm{kGy}$ & $6.08 \pm 0.08^{\mathrm{bA}}$ & $6.06 \pm 0.01^{\mathrm{bA}}$ & $5.95 \pm 0.04^{\mathrm{abA}}$ & $5.86 \pm 0.11^{\mathrm{aA}}$ & $6.10 \pm 0.1^{\mathrm{bA}}$ \\
& $5 \mathrm{kGy}$ & $6.16 \pm 0.03^{\mathrm{aA}}$ & $6.51 \pm 0.01^{\mathrm{bC}}$ & $6.56 \pm 0.3^{\mathrm{bC}}$ & $6.21 \pm 0.1^{\mathrm{aB}}$ & $6.46 \pm 0.1^{\mathrm{bB}}$ \\
\hline
\end{tabular}

Values with different letters $(\mathrm{a}-\mathrm{d})$ within a row differ significantly $(\mathrm{p}<0.05)$; values with letters $(\mathrm{A}-\mathrm{D})$ within a column differ significantly $(\mathrm{p}<0.05)$; values are given as mean \pm standard deviation

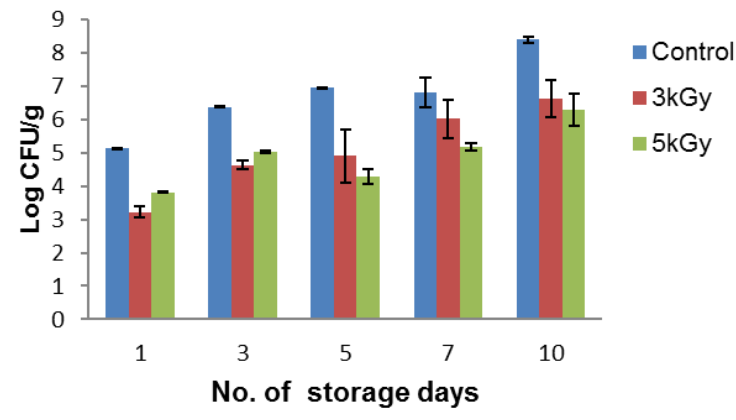

Figure 1. Total mesophilic counts $(\log \mathrm{CFU} / \mathrm{g})$ in irradiated and non- irradiated squid samples on different days of refrigeration $\left(4^{0} \mathrm{C}\right)$; vertical bars indicate error

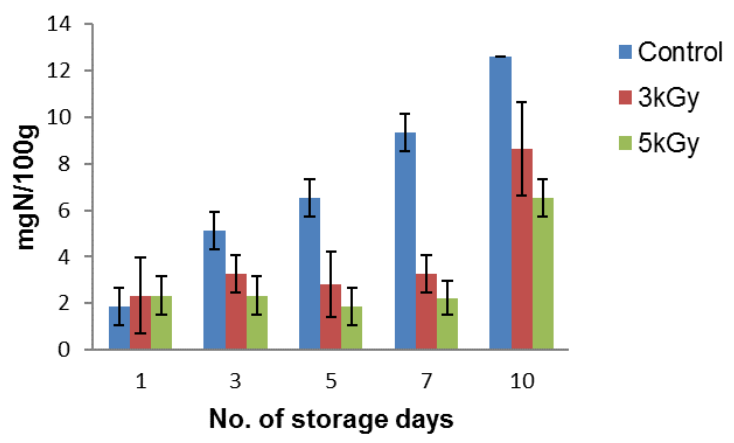

Figure 3. TMA-N of irradiated and non - irradiated squid samples on different days of refrigeration $\left(4^{0} \mathrm{C}\right)$; vertical bars indicate error

(Venugopal et al., 1999). The acceptable limit of the TVB-N in fish is a maximum of $35 \mathrm{mg} \mathrm{N} / 100 \mathrm{~g}$ (Huss, 1988). In the present study, the TVB-N value did not cross the acceptable limit of $35 \mathrm{mg} \mathrm{N} / 100 \mathrm{~g}$ in the irradiated squid meat even after 10 days of storage. Our results are comparable to an earlier study, wherein the TVB-N in iced European sea bream did not increase

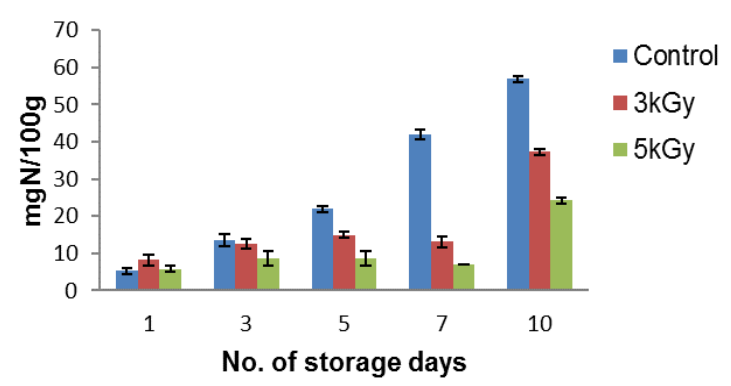

Figure 2. TVB-N of irradiated and non-irradiated squid samples on different days of refrigeration $\left(4^{0} \mathrm{C}\right)$; vertical bars indicate error

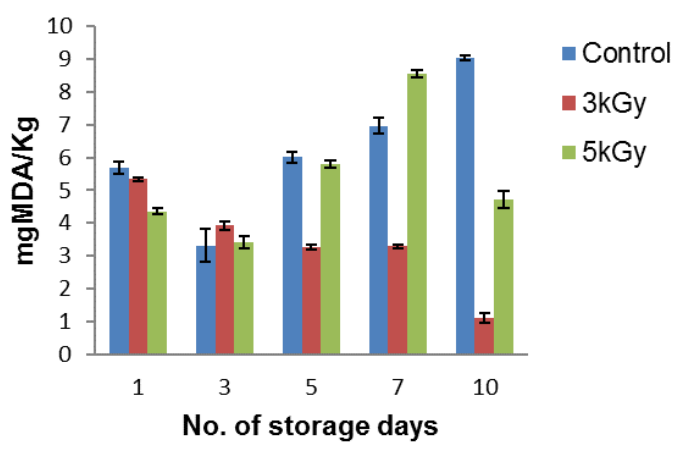

Figure 4. TBARS of irradiated and non- irradiated squid samples on different days of refrigeration $\left(4^{0} \mathrm{C}\right)$; vertical bars indicate error

even after 20-22 days of storage (Castro et al., 2006). Lower TVB-N levels in the irradiated samples as compared with the control was also reported for fish (Jo et al., 2004). Mendes et al. (2005) reported that the initial TVB-N level of $15.6 \mathrm{mg} \mathrm{N} / 100 \mathrm{~g}$ in chilled horse mackerel reached a maximum limit of $30-35 \mathrm{mg} \mathrm{N} / 100 \mathrm{~g}$ on day 12 in the non-irradiated samples, while in the 1 
and 3 kGy irradiated samples, the TVB-N values recorded were 13.6 and $12.7 \mathrm{mg} \mathrm{N} / 100 \mathrm{~g}$, respectively, on days 20.

\subsubsection{Trimethyl amine nitrogen (TMA-N)}

TMA-N is considered as a valuable tool to evaluate the quality of fish and shellfish because of its rapid accumulation in the muscle under refrigerated conditions (Gokodlu et al., 1998). In the present investigation, the initial average values were $<2 \mathrm{mg} \mathrm{N} / 100 \mathrm{~g}$ indicating the freshness of the initial product. The TMA-N levels increased in all the samples $(p<0.05)$, but the values in the irradiated samples remained lower than those of the non-irradiated samples during the refrigeration storage of 10 days. The initial TMA-N level of the squid meat was as low as $1.87 \mathrm{mg} \mathrm{N} / 100 \mathrm{mg}$, and subsequently, the TMA-N levels raised significantly both in the control and irradiated squid at refrigerated storage, but the values in the irradiated group remained lower than the rejection limit (Table 1 and Figure 3).

Ahmed et al. (1997) reported that the rate of formation of TMA-N and TVB-N was reduced in the irradiated fish compared with the non-irradiated samples because of the radiation sensitivity of Pseudomonas and Shewanella, which are the microorganisms responsible for the decomposition of tri- methylamine oxide (Spinelli and Pelroy, 1969). Connell (1975) suggested that TMA$\mathrm{N}$ values between $10-15 \mathrm{mg} \mathrm{N} / 100 \mathrm{~g}$ of fish muscle were at the upper limit of acceptability, while according to Yanamura (1938), the acceptable limit of TMA-N was $30 \mathrm{mg} \mathrm{N} / 100 \mathrm{~g}$ for marine fish. Microbial activities are also implicated in the formation of chemical compounds such as TVB-N, TMA-N, etc., which are suggested as indicators of fish quality (Gram and Huss, 1996).

\subsubsection{Thiobarbituric acid reactive substance} (TBARS)

An increase in the TBARS value was noticed in all the samples during refrigeration storage (Figure 4). The initial TBARS value of the non-irradiated control sample was $5.70 \mathrm{mg} \mathrm{MDA} / \mathrm{Kg}$ with the value increasing to 9.04 mg MDA/ Kg on the $10^{\text {th }}$ day of storage. It was observed that the TBARS values of the irradiated samples ( 3 and 5 $\mathrm{kGy}$ ) were higher than the control group during the 10 days of storage suggesting that lipid oxidation was initiated by gamma irradiation and that the TBA values of the squid increased in direct proportion to the irradiation dose. In addition, the increase in TBA values at the end of 10 days storage at $4^{\circ} \mathrm{C}$ was also found to be statistically significant $(\mathrm{p}<0.05)$. According to Connell (1990), the ideal TBA value should be $<3 \mathrm{mg}$ malonaldehyde $/ \mathrm{kg}$. However, this limit was observed to increase during subsequent storage in the control as well as irradiated squid samples (Table 1 and Figure 4).The highest TBA value recorded for $5 \mathrm{kGy}$ was $4.72 \mathrm{mg}$ malonaldehyde $/ \mathrm{kg}$ on the $10^{\text {th }}$ day of storage.

The formation of thiobarbituric acid reactive substances (TBARS) did not show a consistent trend during refrigerated storage for both the control and irradiated groups. The variations can be explained as a result of the different phases of decomposition of the peroxides, formation of carbonyls, and the interaction compounds with nucleophilic molecules present in the shrimp (Aubourg et al., 2004). Similar results have been reported for irradiated sea bass and anchovy threadfin bream (Lakshmanan et al., 1999; Jeevanandam et al., 2001; Chouliara et al., 2005, Hocaoglu et al., 2012). In the case of non-irradiated squid, the TBA value increased to a maximum of $9.04 \mathrm{mg}$ malonaldehyde $/ \mathrm{kg}$ during the 10 days of storage. Significant differences $(p<0.05)$ in the TBA values were found between the control and the irradiated squid samples during the storage period. This indicates that the lipid oxidation in the squid meat increased due to gamma irradiation.

\section{$3.2 \mathrm{pH}$}

The initial $\mathrm{pH}$ value of the fresh non-irradiated squid was 6.42 , while for 3 and $5 \mathrm{kGy}$ irradiated squid meat, the $\mathrm{pH}$ was 6.08 and 6.16, respectively. Increasing the applied irradiation dose resulted in a decrease in the $\mathrm{pH}$ value. During the course of refrigerated storage, the $\mathrm{pH}$ values showed a decrease in all the squid samples. On further storage, the $\mathrm{pH}$ values of both non-irradiated and irradiated squid samples were in the range of 6.426.46 , and on the $10^{\text {th }}$ day of storage, no definite trend was observed. However, the non-irradiated samples showed a higher $\mathrm{pH}$ than the irradiated ones. This is probably due to the accumulation of nitrogenous compounds, resulting from chemical and biological decomposition, but there was no significant difference in $\mathrm{pH} \quad(p<0.05)$ between the samples. A similar trend was observed for farmed sea bass and turbot on ice (Papadopoulos et al., 2004). From the present study, it was found that the irradiated squids, when stored at refrigeration temperature $\left(4^{\circ} \mathrm{C}\right)$ for 10 days, showed acceptable biochemical quality indices, which may be due to the combined effect of the two preservation methods.

\subsection{Microbiological analysis of squid samples held at refrigeration temperature $\left(4^{\circ} \mathrm{C}\right)$}

The present study is focused on the monitoring of the 
following microorganisms: mesophilic aerobic bacteria, Coliforms, Escherichia coli, Staphylococcus aureus, Salmonella, and Vibrios. The initial counts of mesophilic bacteria in the non- irradiated squid was $5.12 \log$ CFU/g and $8.41 \log \mathrm{CFU} / \mathrm{g}$ for day 0 and 10 , respectively. The effect of gamma irradiation and refrigerated storage on the microbial counts in the squid samples is presented in Figure 1. The number of aerobic plate counts and coliforms decreased with the increase in irradiation dose. Depending on the absorbed dose, the level of viable microorganisms also decreased immediately after irradiation. Pathogens such as Salmonella, S. aureus, and $E$. coli were not detected in any of the squid samples. Irradiation doses of 3 and $5 \mathrm{kGy}$ produced an immediate reduction of 2 and $3 \log$ units of aerobic plate counts, respectively, in the squid. Further, a fish irradiation dose ranging from 1 to $5 \mathrm{kGy}$ has been suggested for shelf life extension (Venugopal et al., 1999; Jo et al., 2004). Chen et al. (1996) and Mendes et al. (2005) reported that the mesophilic bacterial counts of irradiated shrimp, crab, and fish were lower than those in the non- irradiated samples during storage at $4^{\circ} \mathrm{C}$. In this study, gamma irradiation and refrigerated storage were more effective than either treatment alone in decreasing the mesophilic counts and total coliforms. The total aerobic plate count (APC) in fishery products is a useful tool for quality evaluation of shelf life and post- processing contamination. Psychrotrophic bacteria are a major group of microorganisms, especially responsible for spoilage of fresh seafood (Huss, 1994). It was observed that irradiation affected bacterial growth during the initial period (Figure 1).

The total bacterial count presented in Figure 1 shows that at the beginning of the storage period, the bacterial growth was affected by irradiation. A decrease in the viable microorganism count was observed immediately after irradiation depending upon the absorbed dose. The total microbial count limit recommended by the International Commission of Microbiological Specification for Foods Bulletin (ICMSF, 1986) is 5.70$6.00 \log \mathrm{CFU} / \mathrm{g}$ for frozen shell fishes. Hence, the total mesophilic counts reported in the present investigation suggest that the irradiated squid samples remained within the acceptable limits after storage for 10 days at $4^{\circ} \mathrm{C}$. The coliforms were detected in the control sample in the beginning; however, after irradiation at 3 and $5 \mathrm{kGy}$, the counts reduced to zero in all the samples. Gamma irradiation was found to inhibit microbial proliferation in fish and seafood (Radomyski et al., 1994). Similar results were obtained by Cozzo-Siqueira et al. (2003), wherein they did not find $S$. aureus in the irradiated and non-irradiated tilapia (Oreochromis niloticus) fish irradiated with different doses $(1.0,2.2$, and $5 \mathrm{kGy})$ and stored for $20-30$ days at $0.5^{\circ} \mathrm{C}$ and $-2^{\circ} \mathrm{C}$. In the irradiated samples, there was dose dependent reduction in the viable cells immediately after irradiation. The results indicate that irradiation at $3 \mathrm{kGy}$ or above are effective in securing the microbial safety of the squid. Generally, just after irradiation with doses of 3 and $5 \mathrm{kGy}$, the microbial load significantly reduced $(\mathrm{p}<0.05)$ and the irradiated samples showed good microbial quality. Salmonella, E. coli, and $S$. aureus were absent during the entire storage period.

\section{Conclusion}

The results obtained from this study show that the combination of gamma irradiation and refrigerated storage resulted in a significant reduction of bacterial growth, and irradiation of 3.0 and $5.0 \mathrm{kGy}$ doses with refrigerated $\left(4^{\circ} \mathrm{C}\right)$ storage could inhibit coliforms completely. The results also show that the employed radiation dose of 3.0 and $5.0 \mathrm{kGy}$ in conjunction with refrigeration storage extended the shelf life of squid to about 10 days. The levels of $\mathrm{pH}$, TVB-N, TMA- $\mathrm{N}$ and TBARS in irradiated and non- irradiated squid samples were also examined. The irradiated samples had significantly lower concentrations of TVB-N and TBARS during refrigerated storage as compared to the control, which may be attributed to the reduction of the microbial population. These parameters are within the acceptable limits until the last day of refrigeration storage in the irradiated samples. The results revealed that gamma irradiation at high dose $(5 \mathrm{kGy})$ might enhance lipid oxidation, although the growth of microorganisms was inhibited. In conclusion, the results of the study demonstrated that the combination of gamma irradiation and refrigerated storage resulted in a significant reduction of bacterial growth and stabilised the biochemical attributes of the squid.

\section{Acknowledgements}

The financial assistance from Board of Research in Nuclear Sciences (BRNS), Mumbai, Department of Atomic Energy, Government of India [Grant No. 2013/35/4/BRNS] for carrying out this work is gratefully acknowledged. The help and encouragement extended by the Principal Collaborator and the Centre for Radioisotopes and Radiation Technology (CARRT), Mangalore, is appreciated and acknowledged. 


\section{References}

Ahmed, I.O., Alur, M.D., Kamat, A.S., Bandekar, J.R. and Thomas, P. (1997). Influence of processing on the extension of shelf life of Nagli fish (Sillago sihama) by gamma radiation. International Journal of Food Science and Technology, 32, 325-332.

AOAC. (2010). Official method of analysis of AOAC International. Vol. 2. $18^{\text {th }}$ ed. Virginia: Association of Official and Analytical Chemists International.

APHA. (2000). Compendium of Methods for the Microbiological Examination of Food. 3rd ed. Washington: American Public Health Association.

Arvanitoyannis, I.S. and Stratakos, A.C. (2010). Effect of irradiation on fish and seafood. In Irradiation of Food Commodities, p. 287-365, London: Academic Press.

Aubourg, S.P., Pérez-alonso, F. and Gallardo, J.M. (2004). Studies on rancidity inhibition in frozen horse mackerel (Trachurus trachurus) by citric and ascorbic acids. European Journal of Lipid Science and Technology, 106(4), 232-240.

Beatty, S.A. and Gibbons, N.E. (1937). The measurement of spoilage in fish. Journal of Biological Board of Canada, 3, 77-91.

Bustos-Griffin, E., Hallman, G.J. and Griffin, R.L. (2015). Phytosanitary irradiation in ports of entry: a practical solution for developing countries. International Journal of Food Science and Technology, 50(1), 249-255.

Castro, P., Penedo pardon, J.C., Cansino, M.J., Sanjuan Velazquez, E. and Millán, D. L. (2006). Total volatile base nitrogen and its use to assess freshness in European sea bass stored in ice. Food Control, 17, 245-248.

Chen, Y.P., Andrews, L.S. and Grodner, R.M. (1996). Sensory and microbial quality of irradiated crab meat products. Journal of Food Science, 61, 1239-1242.

Chouliara, I., Savvaidis, L.N., Riganakos, K. and Kontaminas, M.G. (2005). Shelf-life extension of vacuum-packaged sea bream (Sparus aurata) fillets by combined $\gamma$-irradiation and refrigeration: microbiological, chemical and sensory changes. Journal of the Science of Food and Agriculture, 85, 779-784.

Connell, J.J. (1975). Control of fish quality. West Byfleet Survey: Fishing News Books Ltd.

Connell, J.J. (1990). Methods of assessing and selecting for quality. In Control of fish quality. London: Fishing News Books Ltd.

Cozzo-Siqueira, A., Oetterer, M. and Gallo, C. (2003).
Effects of irradiation and refrigeration on the nutrients and shelf life of tilapia (Oreochromis niloticus). Journal of Aquatic Food Products Technology, 12, 85-101.

Gokodlu, N., Ozden, O. and Erkan, N. (1998). Physical, chemical and sensory analysis of freshly harvested sardines (Sardina pilchards) stored at $4^{\circ} \mathrm{C}$. Journal of Aquatic Food Products Technology, 7, 5-15.

Gram, L. and Huss, H.H. (1996). Microbiological spoilage of fish and fish products. International Journal of Food Microbiology, 33, 121-137.

Hocaoglu, A., Demicri, A. S., Gumus, T. and Demicri, M. (2012). Effects of gamma Irradiation on chemical, microbial quality and shelf life of shrimp. Radiation Physics and Chemistry, 81, 1923-1929.

Huss, H.H. (1988). Fresh fish quantity and quality changes. FAO Fisheries, Series No. 29, Rome: Danish International Development Agency.

Huss, H.H. (1994). Assurance of seafood quality. In Fisheries Technical Paper No. 334, Rome: Food and Agricultural Organization.

ICGFI. (2002). International consultative group on food irradiation. A Global Food Safety Tool. Vienna: Official Publication of IAEA.

ICMSF. (1986). Microorganisms in food. Sampling for Microbiological analysis: Principles and specific applications, Canada: University Toronto Press.

Jeevanandam, K., Kakatkar, A., Doke, S.N., Bongirwar, V. and Venugopal, V. (2001). Influence of salting and gamma irradiation on the shelf-life extension of threadfin bream in ice. Food Research International, 34, 739-746.

Jo, C., Lee, N.Y., Hon, S.P., Kim, Y.H. and Byun, M.W. (2004). Microbial contamination of the food materials for manufacturing Korean laver rolls (Kimbab) and the effect of gamma irradiation. Journal of Food Science and Nutrition, 9, 236-239.

Lakshmanan, R., Venugopal, V., Venketashvaran, K. and Bongirwar, D.R. (1999). Bulk preservation of small pelagic fish by gamma irradiation: studies on a model storage system using Anchovies. Food Research International, 32, 707-713.

Mendes, R., Silva, H.A., Nunes, M.L. and Empis, J.M.A. (2005). Effect of low-dose irradiation and refrigeration on the microflora, sensory characteristic and biogenic amines of Atlantic horse mackerel (Trachurus trachurus). European Food Research Technology, 21, 329-335.

Neethiselvan, N., Venkataramani, V.K. and Srikrishnadhas, B. (2001). Reproductive biology of 
siboga squid Doryteuthis sibogae (Adam) from Thoothukkudi (Tuticorin) coast, south west coast of India. Indian Journal of Marine Sciences, 30(4), 257 -260 .

Papadopoulos, V., Chouliara, I., Badeka, A., Savvaidid, I.N. and Kontominas, M.G. (2000). Effect of gutting on microbiological, chemical and sensory properties of aquacultured sea bass (Dicentrarchus labrax). Food Microbiology, 20, 411-420.

Raghavan, S. and Hultin, H.O. (2005). Model system for testing the efficacy of antioxidants in muscle foods. Journal of Agriculture Food Chemistry, 53, 45724577.

Radomyski, T. Murano, E.A., Olson, D.G. and Murano, P.C. (1994). Elimination of pathogens of significance in food by low dose irradiation. Journal of Food Protection, 57, 73-86.

Smith, J.S. and Pillai, S. (2004). Irradiation and food safety. Food Technology, 58(11), 48-55.

Spinelli, J. and Pelroy, G. (1969). Quality indices that can be used to assess irradiated sea foods. In Kreuzer, R. (Ed.), Freezing and Irradiation of Fish. London: Fishing News Books.

Venugopal, V., Doke, S.N. and Thomas, P. (1999). Radiation processing to improve the quality of fishery products. Critical Review in Food Science and Nutrition, 39(5), 391-440.

Viji. P., Tanuja. S., Georg. N., Zynudheen A.A. and Lalitha K.V. (2014). Quality characteristic and shelf life of sutchi cat fish (Pangasianodon hypophthalmus) steaks during refrigerated storage. International Journal of Agriculture and Food Science Technology, 5, 105-116.

Vyncke, W. (1981). In Proceedings of the $12^{\text {th }}$ Western European Fish Technologists Association (WEFTA) meeting, Denmark.

Yanamura, Y. (1938). The putrefactive degree and $\mathrm{pH}$ value of fish muscle. Japan Society for Science. Fish Journal, 2, 101-108. 